\title{
Strategi Kepala TK dalam Meningkatkan Mutu Pendidikan pada Masa Pandemi Covid 19
}

\author{
Cucu Jajat Sudrajat ${ }^{1 凶}$, Mubiar Agustin $^{2}$, Leli Kurniati ${ }^{3}$, Dede Karsa ${ }^{4}$ \\ Pendidikan Anak Usia Dini, Universitas Pendidikan Indonesia \\ DOI: $10.31004 /$ obsesi.v5i1.582
}

\begin{abstract}
Abstrak
Guncangan dahsyat Covid 19, telah menginfeksi setidaknya 6 juta orang di dunia dan hampir 400.000 orang diantaranya meninggal dunia. Akibatnya kehidupan manusia di berbagai sektor terguncang hebat, termasuk sektor pendidikan. Pembelajaran daring disemua jenjang pendidikan tak terkecuali PAUD, adalah solusi terbaik saat ini. Kepala sekolah perlu melakukan langkah strategis agar proses pendidikan PAUD tetap berjalan dan kualitas tetap terjaga. Tujuan penelitian ini adalah mendeksripsikan bagaimana strategi kepala sekolah dalam meningkatkan mutu pendidikan taman kanak-kanak pada masa pandemi Covid 19 di Kota Cimahi. Penelitian ini menggunakan pendekatan kuantitatif dengan metode deskriptif survei. Subjek penelitian adalah 112 Kepala TK di Kota Cimahi. Hasil penelitian menunjukan, strategi kepemimpinan kepala sekolah dalam meningkatkan mutu pendidikan TK pada masa pandemi Covid 19 sangat baik (85,90\%). Process Approach $(88,24 \%)$ merupakan skor teringgi, menunjukan pendekatan proses menjadi prioritas utama dilakukan. Sedangkan tanggung jawab (81,21\%) merupakan skor terendah, menunjukan belum optimalnnya pelaksanaan kepemimpinan kepala sekolah masa pandemi covid 19.
\end{abstract}

Kata Kunci: strategi kepemimpinan kepala sekolah; mutu pendidikan tk; pandemi covid 19.

\begin{abstract}
Covid 19, has infected nearly 6 million and killed 400,000 people in the world. Consequently, all areas of human life are disrupted, including the education. Online learning at all levels including Kondergarten, is the best solution at the moment. Principals must take strategic steps, so that education process running well and quality is maintained. The purpose of this study is to describe how the principal's strategy in improving the quality of kindergarten education during the Covid 19 pandemic in Cimahi City. Quantitative approach and descriptive survey are the method of this study. Subjects were 112 Kindergarten Heads. The results showed, the principal's leadership strategy in improving the quality of kindergarten was very good with a score of $85.90 \%$. The Process Approach $(88.24 \%)$ is the highest score, indicating the process approach is the top priority. Responsibility $(81.21 \%)$ is the lowest score, indicating that the principal's leadership implementation is not so optimal.
\end{abstract}

Keywords: principal leadership strategy; kindergarten education quality; covid 19 pandemic.

Copyright (c) 2020 Cucu Jajat Sudrajat, Mubiar Agustin, Leli Kurniati, Dede Karsa

$\triangle$ Corresponding author :

Email Address : cucu0881@upi.edu (Bandung, Jawa Barat, Indonesia)

Received 9 June 2020, Accepted 7 July 2020, Published 11 July 2020

508 | Jurnal Obsesi : Jurnal Pendidikan Anak Usia Dini, 5(1), 2021 


\section{PENDAHULUAN}

Mengguncangnya wabah Virus Corona di hampir seluruh negara di dunia membawa dampak yang besar terhadap berbagai bidang kehidupan manusia, baik ekonomi, social, kesehatan, keamanan maupun pendidikan. Pandemi yang diawali dari Wuhan China dengan tingkat penyebarannya yang cepat dan massive telah menginfeksi 5.701.257 jiwa dan menyebabkan 370.450 orang meninggal di dunia (Kompas 28 Mei 2020) . Kondisi ini membawa rasa takut bagi manusia di bumi, sehingga berbagai strategi telah dilakukan untuk memutus mata rantai penyebaran covid 19 ini. Dunia pendidikan yang menjadi pondasi utama pengembangan sumber daya manusia, tidak luput dari guncangan pandemi Covid 19. Salah satunya adalah terganggunya kegiatan pembelajaran di semua jenjang pendidikan. Hal ini diakui oleh (UNESCO) bahwa wabah Virus Corona telah berdampak terhadap sektor pendidikan. Setidaknya 300 juta siswa mengalami gangguan dalam kegiatan pembelajaran diseluruh dunia dan mengancam hak-hak memperoleh pendidikan mereka di masa yang akan datang depan (Kompas, 05 Maret 2020)

Indonesia menjadi salah satu negara yang terdampak Covid 19 dengan tingkat kematian tebanyak di asia (Beritasatu.com, 26 April 2020). Sebagai langkah anstisipatif maka pemerintah mengeluarkan kebijakan, dengan mewajibkan pembelajaran online di semua jenjang pendidikan. Kebijakan ini berlaku di seluruh lembaga pendidikan baik di tingkat pusat maupun daerah. Kebijakan ini merupakan langkah efektif yang bisa dilakukan di masa pandemi, karena interaksi antar manusia itu tidak harus bertemu langsung, tidak harus bersentuhan atau bertatap muka langsung, akan tetapi bisa melalui media cetak, teknologi dan media social (Adiwijaya,2020).

Pendidikan Anak Usia Dini (PAUD) merupakan lembaga pendidikan formal pada jenjang pendidikan pra sekolah, tentunya memiliki sistem pembelajaran yang berbeda dengan jenjang diatasnya. Karena anak usia dini adalah usia emas yang perlu mendapatkan pelayanan khusus secara langsung. Mewabahnya Covid 19 ini telah menyulitkan dalam pelaksanaan proses pembelajaran di sekolah. Betapa tidak interaksi pembelajaran yang seharusnya dilakukan secara langsung dengan melibatkan semua aspek perkembangan harus berubah menjadi pembelajaran jarak jauh. Hal ini tentunya akan mempengaruhi proses tumbuh kembang anak yang biasa dilakukan secara tatap muka. Karena anak usia dini adalah sosok yang memerlukan sentuhan kehangatan dan komunikasi yang intens baik verbal maupun non verbal (Agustin, dkk, 2020) selain itu anak usia dini memerlukan motivasi melalui permainan-permainan yang hanya bisa dilakukan secara tatap muka. Akibatnya proses tumbuh kembang anak yang menjadi program PAUD tidak optimal dilakukan, padahal peran Pendidikan Anak Usia Dini memiliki peranan yang sangat penting dalam pengembangan potensi awal anak, untuk memenuhi tumbuh kembang anak agar memiliki kesiapan saat mengikuti pendidikan selanjutnya. Hal ini sesuai dengan UUSPN No. 20 tahun 2003 pasal 1 ayat 14 dijelaskan bahwa Pendidikan Anak Usia Dini (PAUD) adalah suatu strategi pembinaan yang ditujukan kepada anak sejak lahir sampai dengan usia enam tahun yang dilakukan melalui pemberian rangsangan pendidikan dalam membantu tumbuh kembang baik maupun rohani agar anak memiliki kesiapan dalam memasuki pendidikan selanjutnya.

Untuk mewujudkan peran dan pungsi PAUD tersebut, harus dimulai dari pemimpin, dalam hal ini adalah kepala sekolah. Kepala sekolah PAUD sangat diperlukan agar PAUD mampu memberikan layanan terbaik kepada peserta didik, orang tua dan masayarakat sebagai customer. Pelayanan terbaik kepada customer merupakan salah satu cerminan sekolah yang berkualitas (Darling F., 1992; Salis,2012;Hoyle, 2007; Sa'ud, 2004). Mewabahnya Covid 19 sangat berpengaruh kepada aspek layanan sekolah dalam melaksanakan proses pendidikan mulai dari perencanaan, pelaksanaan dan penilaian. Kepala sekolah sebagai penanggungjawab tertinggi di sekolah perlu melakukan strategi-strategi khusus agar proses pendidikan dan peningkatan mutu sekolah dapat berjalan secara beriringan (Blomqvist, dkk, 2016; Akdon, 2011;Arifin, 2011). 
Strategi kepemimpinan merupakan serangkaian rencana sistematis (Bell, 2010), namun dapat juga bermakna taktik dan seni dalam perang (Botha \& Triegaardt, 2017), serta bisa dikatakan sebagai pembuatan keputusan (Saifulloh \& Muhibbin, 2012) untuk mencapai tujuan organisasi secara efektif dan efisien. Dengan adanya strategi kepemimpinan, maka sebuah organisasi akan mampu memperoleh posisi yang kuat dalam lingkungannya. karena organisasi tersebut memiliki pengetahuan (knowledge) dan pengalaman (experience) yang lebih baik dalam melaksanakan pendekatan bagi pemenuhan kebutuhan dan permintaan pelanggan (customer) di lingkungan organisasi tersebut berada ( Markides, 2004). Strategi kepemimpinan kepala sekolah dalam meningkatkan mutu pendidikan anak usia dini dimasa pandemi Covid 19, merupakan suatu upaya, seni, teknik yang dilakukan oleh kepala sekolah untuk menggerakkan seluruh komponen sekolah untuk bersama-sama mewujudkan sekolah yang bermutu baik dalam jangka jangka pendek maupun jangka panjang.

Pendidikan Anak Usia Dini yang bermutu merupakan sekolah yang dinantikan oleh masyarakat, karena masyarakat ingin memberikan sekolah yang berkualitas, sehingga anakanak mereka mendapatkan pendidikan yang terbaik dari sekolah tersebut. Sallis (2012) mengemukakan bahwa ada 13 kriteria sekolah berkualitas yaitu: (1) customer focus (2) Problem Solving, (3) Resourches Quality (4) Strategy Quality, (5) Feed back on Customer Complaint, (6) Planning and Policy Strategy, (7) Improvement Process, (8) Creativity, (9) Responsibilty, (10) Evaluation Strategy, (11) Maintaining Quality (12) Culture Work Quality, (13) Continous Quality Improvement. Kriteria sekolah berkualitas di atas merupakan sistem manajemen mutu yang sering menjadi rujukan lembaga pendidikan untuk meningkatkan kualitas lembaganya. Pada jenjang PAUD, lebih khusus Ishimine, K., \& Bennett, J. (2010) mengemukan bahwa PAUD berkualitas di diukur dari kualitas proses interaksi, kualitas lulusan, keterlibatan orang tua dalam pendidikan, kualitas kepemimpinan kepala sekolah, konsep dan praktik pembelajaran, serta kualitas manajemen.

PAUD yang bermutu juga didukung oleh berbagai faktor baik dari sisi SDMnya yang unggul, sarana prasarana yang memadai, sistem manajemen efektif maupun kepemimpinan kepala sekolah yang visioner. Dalam sistem pendidikan di sekolah, kepemimpinan kepala sekolah sangat menentukan dalam memperlancar kegiatan pembelajaran. Peranannya tidak hanya menguasai teori-teori kepemimpinan kepala sekolah, akan tetapi seorang kepala sekolah harus mampu mengimplementasikan kemampuannya dalam aplikasi di lapangan secara real. Untuk itu seorang kepala sekolah dituntut untuk memiliki ilmu pendidikan secara menyeluruh ( Akdon, 2009). Kepala sekolah sebagai pemimpin mempunyai peran sangat penting dalam mengembangkan kualitas pendidikan di sekolah, oleh karena itu ia harus berupaya mengembangkan kapasitas kepemimpinannya secara efektif di berbagai tingkatan, mulai diri sendiri, orang lain, sampai dengan organisasi, dengan memenuhi peran dan tanggung jawabnya ( Nanda V., 2005; Sturm, Vera, D., \& Crossan, M., 2016).

Pelaksanaan peran dan tanggung jawab kepala sekolah di masa pandemi ini tentu tidak akan optimal manakala tidak dilakukan strategi-strategi oleh kepala sekolah dalam pelaksanaan kepemimpinannya. Oleh karenanya kepala sekolah memerlukan kemampuan leadership yang baik dengan menguasai kompetensi sebagai kepala sekolah ( Bush \& Coleman, ,2012: Patterson, 2016), hal ini diperkuat dengan Permendikbud Nomor 6 Tahun 2018 tentang Penugasan Guru Sebagai Kepala Sekolah, dikatakan bahwa kepala sekolah wajib memiliki sertifikat calon kepala sekolah sebagai syarat profesionalisme dalam pelaksanaan tugasnya (manajerial, supervisi dan pengembangan kewirausahaan). Dengan memiliki kompetensi kepemimpinan, kepala sekolah akan mampu melakukan peranannya sebagai pemimpin dalam kondisi apapun . Pandemi Covid 19 yang sedang melanda dunia tidak menjadi penghalang bagi kepala sekolah PAUD untuk tetap melayani customer dalam hal ini peserta didik, orang tua dan masyarakat, baik pelayanan tumbuh kembang anak, parenting, maupun pelayanan kemasyarakatan sebagai bentuk kepedulian kepada lingkungan sekitar. 
Oleh karenanya jabatan kepala sekolah pada PAUD bukanlah jabatan biasa, melainkan jabatan yang istimewa, karena baik buruknya sekolah sangat ditentukan oleh kepemimpinan kepala sekolah dalam mengelola sekolah dan seluruh sumber daya yang ada di di dalamnya ( Hoy, Miskel, G., 2005.). Dengan demikian bahwa menjadi kepala sekolah harus siap dengan segala konsekwensi perubahan yang terjadi (Suarga, 2017; Tambunan S., 2015) sehingga penunjukkan kepala sekolah idealnya harus sesuai dengan kompetensi yang dibutuhkan. Kondisi real di lapangan, bahwa sebagian besar PAUD besar di dirikan oleh masyarakat melalui Yayasan, sehingga tak jarang pemilihan kepala sekolah yang ditunjuk tidak berdasarkan kompetensi yang seharusnya dimiliki kepala sekolah. Akibatnya banyak sekolah Taman Kanak- Kanak yang tutup, karena kalah bersaing dengan TK lain yang lebih berkualitas.

Pada masa pandemi Covid 19 proses penyelenggaraan dan peningkatan mutu pendidikan pada PAUD, akan menjadi tantangan tersendiri bagi kepala sekolah untuk mencurahkan segala kemampuannya mengimplementasi keterampilan memimpinnya, serta menerapkan ide dan gagasannya agar proses pendidikan di sekolah tetap berjalan sesuai tujuan dan mutu sekolah meningkat (Northouse, G. Peter. 2013). Tantangan tersebut akan menguji sejauhmana kepala sekolah mampu melakukan strategi kepemimpinanannya di tengah wabah. Strategi dalam kepemimpinan merupakan kunci kesuksesan sebuah organisasi dalam mencapai tujuan (Rivai, Veithzal, 2004; Wahjosumidjo, 2007.). Pada Pandemi Covid 19 tantangan kepala sekolah PAUD semakin besar, dimana tuntutan orang tua akan perkembangan tumbuh kembang anaknya, nuansa ketakutan efek berita perkembangan virus, keluhan ekonomi yang berdampak pada pembayaran sekolah, serta kesibukan orang tua yang bertambah akibat harus membimbing anaknya belajar, tingkat penguasaan teknologi dari orang tua yang berbeda-beda, serta kebingungan guru dalam metode pembelajaran online yang tepat untuk anak usia dini agar tetap menyenangkan belajar di rumah. Karena pada dasarnya anak akan belajar apabila menyenangkan dan menarik ( Stephen, 2007.).

Peneliti memandang bahwa strategi kepala sekolah dalam meningkatkan mutu pendidikan di Masa Pandemi Covid 19 adalah hal yang sangat crucial, karena PAUD merupakan gerbang anak menuju sekolah yang lebih tinggi. Di sinilah anak akan mengalami pengembangan potensi yang sangat pesat karena masa-masa golden age tingkat perkembangan otak anak berkembang pesat. Agustin M, dan Puspita (2020) mengatakan bahwa berpikir anak pada masa golden age ini sangat pesat, pada masa ini segala potensi kemampuan anak dapat dikembangkan secara optimal. Selain itu dalam konteks PAUD adalah anak-anak usia dini sebagai aset masa depan bangsa ( Agustin M., dkk, 2020; Rodd, J. ,2006.).

\section{METODOLOGI}

Pendekatan penelitian yang digunakan yaitu pendekatan kuantitatif. Metode penelitian yang digunakan dalam penelitian ini adalah penelitian survei. penelitian survei yaitu prosedur penelitian kuantitatif yang dilakukan untuk memperoleh mendeskripsikan sikap, perilaku, dan karakteristik dari populasi yang diperoleh melalui sampel dalam populasi (Creswell, 2012 : 21) Dalam penelitian ini sikap, perilaku dan karakteristik yang dimaksud adalah terkait dengan strategi yang dilakukan kepala kepala sekolah dalam meningkatkan mutu pendidikan taman kanak-kanak di masa pandemi covid 19. Data penelitian diperoleh secara online menggunakan media google form. Jumlah responden yang menjadi sampel dalam penelitian ini adalah 112 kepala sekolah di Kota Cimahi yang terdiri dari 109 orang kepala sekolah berjenis kelamin perempuan dan 3 orang kepala sekolah berjenis kelamin laki-laki yang bearada di wilayah Kota Cimahi. Adapun sebarannya adalah 2,67\% kepala sekolah dari TK Negeri atau sebanyak 3 orang dan 93,33\% kepala sekolah dari TK Swasta atau sejumlah 109 orang. Instrumen yang digunakan dalam penelitian ini adalah angket tentang strategi kepemimpinan yang terdiri dari 24 pernyataan dan angket tentang 
mutu pendidikan terdiri dari 26 pernyataan. Angket dikembangkan dari konsep-konsep pokok strategi kepemimpinan ( Tambunan S., 2015) dan konsep mutu pendidikan ( Hoyle David, 2007; Sallis, 2012) dengan alternatif jawaban menggunakan skala likert (Sangat Sering, Sering, Kadang-kadang, Pernah, Tidak pernah). Pengolahan data menggunakan excel dan spss versi 18. Adapun desain penelitian dapat dilihat pada gambar 1 di bawah ini :

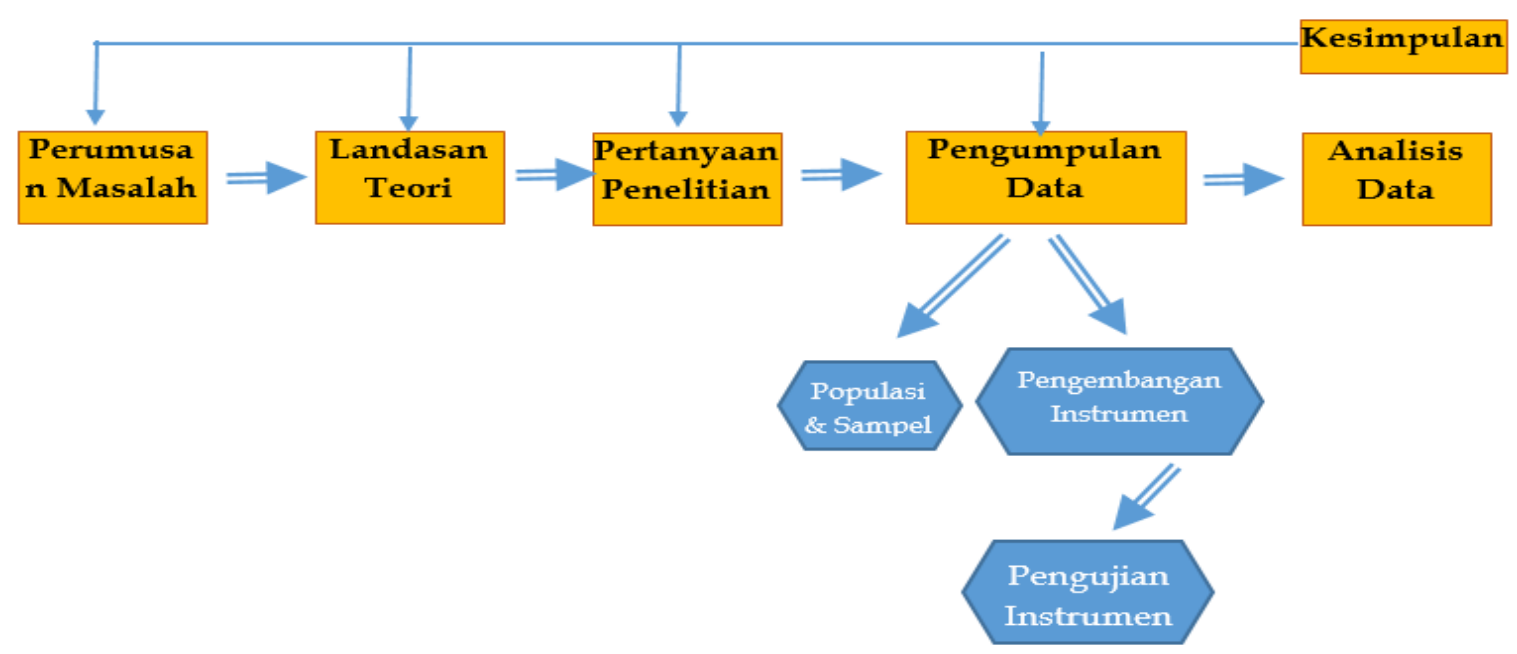

Gambar 1 Desain Penelitian

\section{HASIL DAN PEMBAHASAN}

Hasil penelitian yang akan dideskripsikan bertujuan untuk memberikan gambaran bagaimana strategi kepemimpinan kepala sekolah dalam meningkatkan mutu pendidikan taman kanak-kanak pada masa pandemi Covid 19 di Kota Cimahi. Strategi peningkatan mutu pendidikan oleh kepala sekolah taman kanak-kanak diukur berdasarkan dimensidimensi kepemimpinan dan mutu pendidikan.

Berdasarkan pengolahan data diperoleh data sebagai berikut (1) strategi melayani kepala sekolah taman kanak dalam meningkatkan mutu pendidikan pada masa Covid 19, hasil penelitian menunjukan diemnsi ini berada pada kategori sangat tinggi dengan skor $85,45 \%$; (2) strategi pembuatan keputusan dalam meningkatkan mutu pendidikan taman kanak-kanak pada masa pandemi Covid 19, hasil penelitian menunjukan dimensi ini berada pada kategori sangat tinggi, dengan skor $84,07 \%$; (3) strategi keteladanan yang ditampilkan oleh kepala sekolah pada masa pandemi Covid 19 di Kota Cimahi, hasil penelitian berdasarkan pengolahan data bahwa dimensi ini mendapatkan skor 85,06\%, artinya berada pada kategori sangat tinggi; (4) strategi pelaksanaan tanggung jawab kepemimpinan kepala sekolah dalam meningkatkan mutu pendidikan di masa Covid 19, hasil penelitian menunjukan dalam kategori tinggi dengan skor 81,70\%; (5) strategi kerjasama yang dilakukan oleh kepala sekolah di masa pandemi Covid 19 di Kota Cimahi, dimensi ini berada pada ketgori sangat tinggi dengan skore $88,08 \%$; (6) Strategi menciptakan perubahan yang dilakukan oleh kepala sekolah di masa Pandemi Covid 19, hasil penelitian dari dimensi ini menunjukan skor 87,86\% dengan kategori sangat tinggi; (7) Strategi proses pelayanan terhadap pelanggan (customers focus) dalam hal ini adalah peserta didik dalam meningkatkan mutu pendidikan taman kanak-kanak pada masa pandemi Covid 19 di Kota Cimahi, hasil penelitian menunjukan skor 85,45 atau sangat tinggi; (8) strategi pimpinan dalam menjalankan peran dan kompetensinya sebagai kepala sekolah dalam meningkatkan mutu pendidikan taman kanak-kanak pada masa pandemi Covid 19 di Kota Cimahi, hasil penelitian dimensi ini mendapatkan skor 84,07\% dengan kategori sangat tinggi; (9) strategi keterlibatan semua pendidik dan tenaga kependidikan dalam meningkatkan mutu pendidikan taman kanak-kanak pada masa pandemi Covid 19 di Kota Cimahi, skor yang 
diperoleh adalah 87,98 artinya berada pada kategori sangat tinggi; (10) strategi kepala sekolah taman kanak-kanak di Kota Cimahi untuk melaksanakan pendekatan proses terhadap manajemen dalam dalam meningkatkan mutu pendidikan taman kanak-kanak pada masa Pandemi Covid 19 di Kota Cimahi, pada dimensi ini menunjukan skore 88,21\% atau sangat tinggi; (11) strategi prinsip perbaikan berkelanjutan dilakukan kepala sekolah taman kanak-kanak dalam meningkatkan mutu pendidikan taman kanak-kanak pada masa pandemi Covid 19 di Kota Cimahi, pada dimensi ini hasil penelitian menunjukan kategori yang sangat tinggi dengan skor 87,62\%; (12) strategi pendekatan sistem dilakukan dalam proses pencapaian tujuan lembaga untuk meningkatkan mutu pendidikan taman kanakkanak pada masa Pandemi Covid 19 di Kota Cimahi, data menunjukan skor 87,50\% atau sangat tinggi; (13) strategi pendekatan data dan fakta sebagai alat dalam proses pengambilan keputusan untuk meningkatkan mutu pendidikan taman kanak-kanak pada masa pandemi Covid 19 di Kota Cimahi, skor yang diperoleh berada pada kategori sangat tinggi yaitu $88,13 \%$; (14) strategi kerjasama yang saling menguntungkan dilakukan oleh taman kanakkanak dalam meningkatkan mutu pendidikan pada masa Pandemi Covid 19 di Kota Cimahi, penelitian berdsarkan pengolahan data menunjukan skor $82,38 \%$ atau berada pada kategori tinggi. Hasil Penelitian berdasarkan pegolahan data dapat digambarkan pada grafik yang terdapat pada gambar 2 dibawah ini :

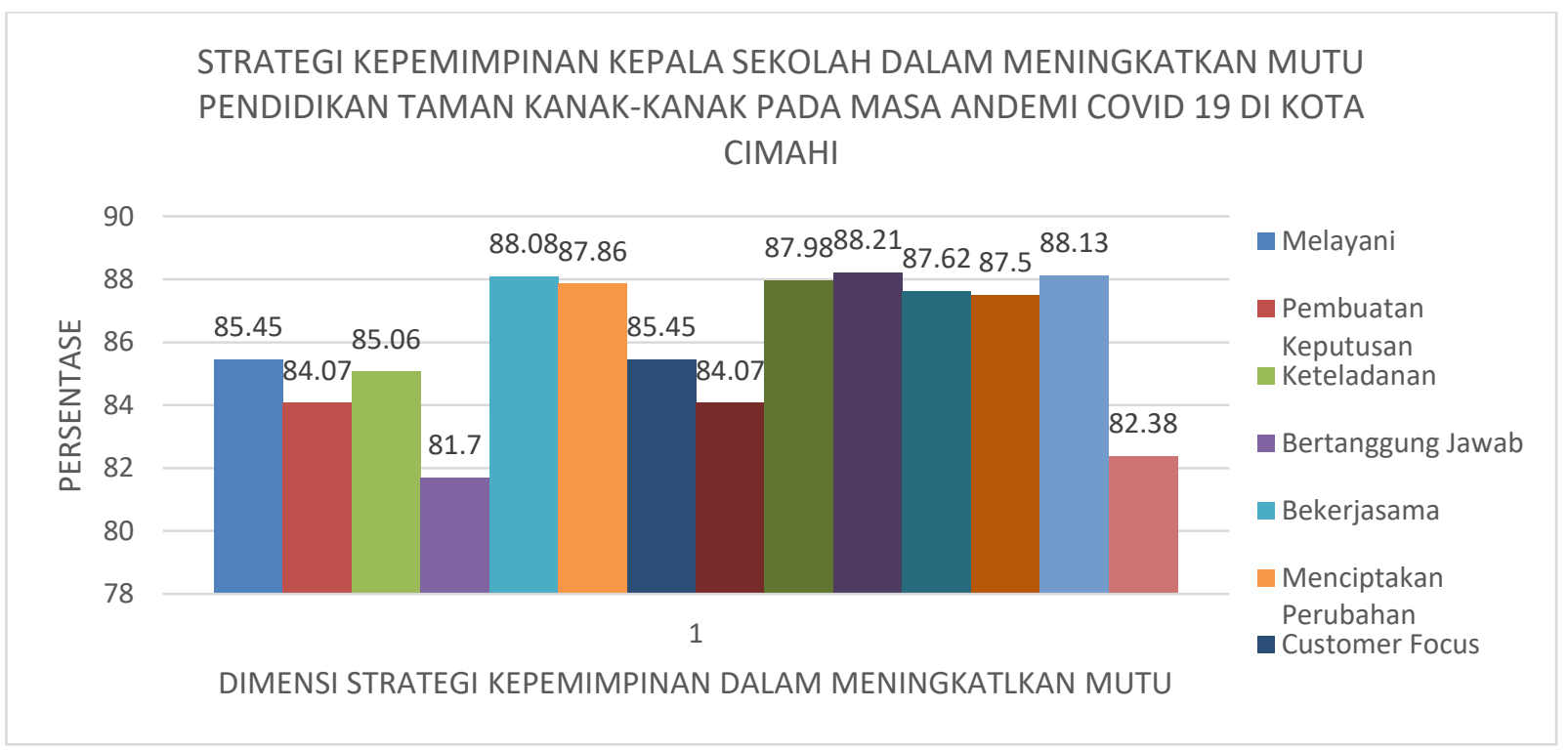

\section{Gambar 1 : Grafik Hasil Penelitian}

Berdasarkan hasil penelitian di atas, dimensi yang akan dieksplorasi lebih jauh adalah dimensi dengan skor tertinggi, terendah dan dimensi secara umum yang diperoleh dari nilai rata-rata. Pengolahan data menunjukan bahwa dimensi yang memiliki persentase tertinggi $(88,21)$ yakni Proces Aproach. Indikator dari dimensi ini di sajikan pada tabel 1.1 di bawah ini :

Tabel 1 Indikator Procces Approach

\begin{tabular}{lc}
\hline \multicolumn{1}{c}{ Indikator } & Skor (\%) \\
\hline Setiap kegiatan diawali dengan perencanaan & 88,04 \\
Perencanaan yang telah dibuat diikuti dengan pelaksanaan & 91,79 \\
Setiap pelaksanaan diikuti dengan pengawasan & 86,61 \\
\hline
\end{tabular}

Pendekatan proses artinya bagaimana aktifitas sekolah dari sistem-sistem yang selama dilakukan di masa pandemi Covid 19 selalu mengikuti alur proses yang terjadi dalam sekolah mulai dari perencanaan, pelaksanaan dan pengawasan. Dengan kata lain 
bahwa hasil yang diinginkan dicapai secara lebih efisien manakala sumber daya dan aktivitas-aktivitas yang berhubungan dikelola sebagai suatu proses. (Kompas, n.d.) menyebutkan bahwa sebuah proses adalah interaksi kegiatan dalam sebuah organisasi. Dalam kajian manajemen mutu terpadu pendekatan proses harus memenuhi kegiatan Plan, Do, Check and Action (PDCA) gagasan ini dipelopori oleh Edward Deming (Kolesar, P., 2005). Dalam hubungannya dengan pendidikan di sekolah, Cheng, Y. C. (2003) mengungkapkan bahwa pendidikan yang berkualitas diperoleh dari suatu proses manajemen yang dilakukan secara konsisten mulai tahap persiapan, pelaksanaan dan tindak lanjut. Tahapan tersebut dilakukan secara berkelanjutan untuk menjamin mutu dari suatu sekolah.

Dalam meningkatkan mutu pendidikan itu pemerintah melalui Peraturan Pemerintah RI nomor 19 tahun 2005 tentang Standar Nasional Pendidikan, yaitu (1) proses pembelajaran pada satu satuan pendidikan diselenggarakan secara interaktif, inspiratif, menyenangkan, menantang, memotivasi peserta didik untuk berprestasi aktif serta memberikan ruang yang cukup bagi prakarsa, kreatifitas dan kemandirian sesuai bakat, minat dan perkembangan fisik serta psikologis peserta didik; (2) dalam proses pembelajaran pendidik dituntut dapat memberikan teladan; (3) setiap satuan pendidikan melakukan perencanaan proses pembelajaran, pelaksanaan proses pembelajaran, penilaian hasil pembelajaran, dan pengawasan proses pembelajaran untuk terlaksananya proses pembelajaran yang aktif dan dinamis. Dari peraturan pemerintah tersebut jelas digambarkan bahwa sebuah pembelajaran di sekolah merupakan suatu proses yang terencana, yang dilaksanakan dengan manajemen yang efektif dan melalui pengawasan untuk dilakukan tindak lanjut.

Pemerataan pendidikan manjadi hambatan dalam peningkatan mutu pendidikan di Indonesia. Mahbub et al. (2020) mendapatkan bahwa distribusi guru tidak merata dan hanya terkonsentrasi di pulau Jawa seperti Jawa Barat, Jawa Tengah, Jawa Timur. Sementara di bagian barat dan timur Indonesia masih ada kekurangan guru. Oleh karena itu pemerataan pendidik perlu mendapatkan perhatian dari pemerintah, utamanya pada tingkat pendidikan anak usia dini.

Taman kanak-kanak sebagai satuan pendidikan yang melayani tumbuh kembang anak usia dini, memerlukan pendekatan proses, karena perkembangan berpikir anak pada usia ini sangat pesat, masa ini segala potensi kemampuan anak dapat dikembangkan secara optimal (Agustin, dkk., 2020). Oleh karena itu keberhasilan dalam pendidikan di taman kanak-kanak tidak bisa diperoleh secara instan tetapi melalui proses yang matang, sehingga menghasilkan produk yang berkualitas. Produk dalam pendidikan adalah lulusan yang berkualitas, dengan produk yang berkualitas maka akan berdampak pada sekolah sehingga mencerminkan kualitas dari taman kanak-kanak itu sendiri.

Dalam peningkatan mutu pendidikan taman kanak-kanak, setiap kegiatan yang akan dilaksanakan harus melalui alur proses yang sistematis, sehingga dihasilkan mutu yang baik pula. Alur proses yang dimaksud adalah proses manajemen mulai dari perencanaan, pelaksanaan, evaluasi dan pengawasan ( Mulyasa, 2012; Juliantoro, 2017). Dalam pendidikan taman kanak-kanak proses manajemen merupakan hal yang sangat penting, agar program dan kurikulum yang diberikan sudah melalui proses. Mulai dari analisis, kemudian dibuat perencanaan, dilanjutkan untuk dilaksanakan dan dievaluasi dan tentunya diawasi apakah sesuai dengan perencanaan ataukah tidak pada saat dilaksanakan. Dengan kata lain bahwa strategi pendekatan proses diterapkan dalam semua kegiatan taman kanak-kanak, sehingga dengan melalui proses yang baik maka kualitas dari kegiatan tersebut lebih terjaga dan akan terus diperbaiki sehingga standar mutu dari sekolah kegiatan akan dapat dicapai.

Hasil penelitian di atas, menunjukan bahwa pendekatan proses menjadi prioritas utama strategi kepemimpinan dalam peningkatan mutu TK pada masa pandemic Covid 19. Gambaran ini menunjukan kepala sekolah berusaha menjalankan kepemimpinannya dengan sangat hati-hati, dimana segala sesuatu dilakukan berdasarkan analisis kondisi, 
perlu perencanaan, perlu prosedur dan pengawasan. Kepala sekolah memahami apa yang harus dan apa yang tidak harus dilakukan dalam menjalankan perannya sebagai kepala sekolah, sehingga proses pendidikan di taman kanak-kanak berjalan sesuai rencana dan kualitas sekolah dapat ditingkatkan. Permasalahan saat ini adalah semua proses pendidikan, baik itu berkaitan dengan pembelajaran maupun manajemen sekolah dilakukan secara daring. Namun pada masa ini kepala sekolah memiliki kesempatan untuk berpikir lebih sistematis dan melaksanakan kepemimpinannya berdasarkan alur proses manajemen. Strategi pendekatan proses yang dilakukan kepala sekolah sebagai strategi kepemimpinan menunjukan bahwa kepala sekolah mampu menjalankan kompetensi manajerialnya. Dimana kompetensi manajerial merupakan aneka ragam kualifikasi itu harus dipandang sebagai hal positif dalam arti memperkaya pengetahuan dan pemahaman yang lebih mendalam tentang apa saja yang harus dilakukan oleh para manajer agar kemampuan organisasi mencapai tujuan dan berbagai sasarannya semakin meningkat (Imsuha, 2016).

Dalam kondisi pandemi Covid 19 yang sangat terbatas dalam sisi interaksi social, Kepala sekolah mampu menunjukan kompetensi sosialnya, dimana kepala sekolah terus berusaha melakukan interaksi dengan semua pihak menggunakan media online, meminta saran bawahan, dan menganalisis kondisi. Disamping itu kepala sekolah dimasa pandemi Covid 19 mampu menunjukan kompetensi supervisi dan kepribadian merupakan bagian yang tidak terpisahkan yang ditunjukan oleh kepala sekolah dalam menghadapi pandemi Covid 19 ini. Salah satunya adalah dengan selalu koordinasi dengan guru dan staf, mencari informasi perkembangan pembelajaran dan menunjukan pribadi yang memperhatikan kondisi bawahan dan fokus terhadap kepuasan pelanggan dalam hal ini siswa dan orang tua. Selain itu pada masa pandemi ini semua aktivitas pendidikan dilaksanakan dari rumah atau kita kenal dengan WFH (Work From Home), Kondisi seperti ini menjadikan kepala sekolah bisa lebih intens dalam melaksanakan tugas secara daring mulai dari perencanaan, pelaksanaan, evaluasi dan pengawasan. Melalui proses manajemen yang baik, maka mutu pendidikan Taman Kanak-Kanak akan terus mampu ditingkatkan walaupun informasi dan instruksi dailaksanakan dari rumah.

Dimensi strategi yang memiliki persentase terendah berdasarkan hasil penelitian adalah tanggung jawab. Dimensi ini melihat sejauhmana strategi pelaksanaan tanggung jawab kepala sekolah pada Taman Kanak di kota Cimahi dalam meningkatkan mutu pendidikan di masa Pandemi Covid 19. Hasil penelitian menunjukan bahwa strategi kepala sekolah dalam meningkatkan mutu pendidikan taman kanak-kanak, berdasarkan dimensi tanggung jawab mencapai $81,21 \%$ hal ini dapat dikatakan bahwa strategi pelaksanaaan tanggung jawab kepemimpinan kepala sekolah telah dilakukan dengan kategori baik. Indikator dari dimensi ini dapat dilihat pada table 2 berikut ini :

Tabel 2 Indikator Tanggung Jawab

\begin{tabular}{ll}
\hline \multicolumn{1}{c}{ Indikator } & Skor $(\%)$ \\
\hline Menyelesaikan tugas kepemimpinan & 86,96 \\
Mempertanggungjawabkan kepada pihak atasan yang & \\
mendelegasikan wewenang tentang hasil yang dicapai & 80,54 \\
Melakukan evaluasi pelaksanaan program & 81,43 \\
Melakukan perbaikan hasil evaluasi & 81,96 \\
\hline
\end{tabular}

Dari indikator di atas, bahwa kepala sekolah memiliki prioritas menyelesaikan tugas kepemimpinan, namun mempertanggungjawabkan kepada atasan, melakukan evaluasi program dan perbaikan evaluasi belum maksimal dilakukan. Hal ini menunjukan bahwa masa pandemi Covid 19 secara umum sangat mempengaruhi pelaksanaan tanggungjawab sebagai kepala sekolah. Hal ini karena kebutuhan akan tumbuh kembang anak yang seharusnya dilaksanakan di sekolah telah berubah menjadi online. Kondisi ini akan membuat kepala sekolah tidak puas dengan tanggung jawab yang diembannya. 
Kepala sekolah sebagai pemimpin memiliki tanggung jawab besar yang wajib diemban sebagai wujud dari mandat organisasi, dorongan ataupun keyakinan orang lain yang mempunyai harapan kepada seseorang pemimpin tersebut buat melaksanakan kepemimpinannya yang lebih baik dari sebelumnya (Jones \& Pound, 2008). Tambunan (2015) menyebutkan bahwa menjadi pemimpin memiliki tanggung jawab besar yang harus diemban sebagai bentuk dari amanah, dukungan atau kepercayaan orang lain yang memiliki harapan kepada seorang pemimpin tersebut untuk melakukan perubahan yang lebih baik dari keadaan sebelumnya, tanggung jawab seorang pemimpin terdiri dari dua tahap yaitu, bertanggungjawab menyelesaikan tugas, mempertanggungjawabkan kepada atasan atau kepada orang yang mendelegasikan wewenang mengenai hasil yang telah dicapai.

Dalam konteks sekolah taman kanak-kanak kepala sekolah sebagai pemimpin memiliki tanggung jawab sepenuhnya terhadap tugasnya untuk kelancaran pelaksanaan pendidikan dan pembelajaran di sekolah serta bertanggung jawab terhadap orang yang memberinya mandat. Di Kota Cimahi dari 112 TK, 109 TK merupakan TK swasta, sehingga tanggung jawab kepala sekolah adalah kepada yayasan yang menunjuknya. Selain itu kepala sekolah harus memahami tugas dan fungsi taman kanak-kanak dan hubungan kerjasama secara individu. Tugas sebagai kepala sekolah dalam pendidikan taman kanakkanak bukanlah merupakan hal yang mudah. Karena sebagai kepala hendaknya pandai menganalisis dan menentukan apa saja yang diperlukan bagi kemajuan sekolahnya, sehingga tujuan pendidikan sekolah itu semaksimal mungkin dapat dicapai (Erlandson, 2014). Kepala sekolah harus mampu menganalisis dan menentukan hal mana yang telah ada dan mencukupi, mana tidak atau belum mencukupi dan perlu di upayakan atau atau dipenuhi, begitu juga masalah tanggung jawab kepala sekolah dalam pendidikan, merupakan syarat utama dalam kepemimpinan kepala sekolah.

Tanggung Jawab menunjukan sebuah kondisi yang didalamnya terkandung normanorma etika, dan sosial yang berarti bahwa perbuatan yang dipertanggung jawabkan itu adalah baik, dapat diterima atau disetujui orang lain, dan mengandung kebenaran selain itu tanggung jawab berisi pula di dalamnya keberanian mengambil resiko terhadap tantangan, hambatan atapun rintangan yang mungkin akan menghalangi tercapainya pekerjaan yang telah diyakini kebaikan dan kebenarannya ( Suarga, 2017). Dengan kata lain tanggung jawab adalah kesanggupan untuk melaksanakan kewajiban yang diberikan kepadanya dengan sebaik-baiknya. Seorang kepala sekolah pada taman kanak-kanak mempunyai peranan kepemimpinan yang sangat berpengaruh di lingkungan sekolah yang menjadi tanggung jawabnya. Tugas kepala sekolah adalah membantu para guru mengembangkan kemampuan-kemampuan mereka secara maksimal dan menciptakan nuansa hidup sekolah dan mendorong pendidik dan tenaga kependidikan, orang tua dan masyarakat untuk mempersatukan kehendak, pikiran dan tindakan dalam kegiatan kerjasama yang efektif bagi tercapainya tujuan-tujuan pendidikan (Wahjosumidjo, 2007). Dengan demikian bahwa kepala sekolah harus terus berupaya melaksanakan tanggung jawabnya sebagai pemimpin agar seluruh program sekolah khususnya di Taman kanak dapat diselesaikan, dengan tanggung jawab yang tinggi oleh kepala sekolah maka kualitas sekolahpun akan Nampak, karena kualitas sekolah akan terlihat dari pemimpin yang melaksanakan tanggung jawab dengan baik.

Pada masa Pandemi Covid 19 kepala sekolah taman kanak-kanak di Kota Cimahi berdasarkan hasil penelitian kepala sekolah telah melaksanakan tanggung jawab dengan baik, walaupun belum optimal karena kondisi wabah yang menyulitkan mereka untuk melaksanakan tanggungjawabnya secara sempurna. Dari sisi mutu sekolah tak dipungkiri upaya kepala sekolah dalam menjalankan tanggung jawabnya baik tanggung jawab secara tugas maupun tanggung jawab secara moral adalah cerminan kualitas kepemimpinan kepala sekolah. Dengan kualitas upaya pelaksanaan tanggung jawab maka membawa dampak kepada kepercayaan masyarakat akan mutu dari taman kanak-kanak yang dipimpinnya. 
Berdasarkan skor rata-rata hasil pengolahan data, hasil penelitian secara umum tentang strategi kepemimpinan kepala sekolah dalam meningkatkan mutu pendidikan taman kanak-kanak pada masa pandemi Covid 19 di Kota Cimahi mencapai angka 85,90 persen dari nilai ideal (100\%), dalam penelitian ini angka tersebut masuk dalam kategori sangat baik. Pada masa Pandemi Covid 19 ini, strategi pada dasarnya adalah teknik, cara, seni atau rencana dalam mencapai tujuan organisasi ( Botha, 2017; Anggraeni, 2016). Kepala sekolah pada taman kanak-kanak sangat memahami arti penting sebuah kualitas, dimana dalam kondisi apapun kualitas harus tetap dijaga. Dengan terjadinya Pandemi Covid 19 kepala sekolah taman kanak-kanak di Kota Cimahi terus berupaya dengan sebaik mungkin menggunakan bebagai cara agar proses pelayanan terhadap peserta didik, orang tua dan masyarakat serta pelayanan di lingkungan internal tetap optimal dilakukan, bahkan bisa membuktikan lebih baik bila dibanding dengan masa-masa sebelum wabah. Dalam penelitian ini peneliti menerapkan dimensi strategi kepemimpinan yang dikolaborasikan dengan teori manajemen mutu untuk mencapai kualitas dari suatu institusi pendidikan.

Dalam penelitian ini hal yang diungkap adalah bagaimana strategi yang dilakukan kepala sekolah taman kanak-kanak di Kota Cimahi dalam meningkatkan mutu pendidikan pada masa Pandemi Covid 19 untuk mencapai sekolah yang bermutu. Pada situasi pandemi Covid 19 dimana proses pendidikan di sekolah dilakukan dengan belajar dari rumah, bekerja dari rumah dan beribadah dari rumah, sesuai dengan instruksi Presiden Jokowi di awal terjadinya wabah, yang ditindaklanjuti dengan instruksi menteri pendidikan dan kebudayaan yang kemudian diberlakukanlah proses pembelajaran dengan metode daring dimana komunikasi kepala sekolah dengan pihak lain dilakukan secara daring. Tentu saja proses peningkatan mutu pendidikan di taman kanak-kanak mengalami hambatan, baik dari sisi komunikasi, pemakaian sarana dan pra sarana, kesulitan keuangan, pengetahuan tentang metode daring yang kurang serta kerjasama dengan pihak lain yang tidak optimal. Namun dari hasil penelitian diperoleh bahwa kepala sekolah dalam menjalankan kepemimpinannya untuk mewujudkan sekolah yang bermutu tetap menjadi prioritas, hal ini menunjukan bahwa dalam situasi apapun seorang pemimpin harus tetap melakukan yang terbaik dalam menjalankan tugasnya. Karena keberhasilan seorang pemimpin akan terlihat manakala ia dihadapkan kepada situasi yang paling buruk, ia akan berusaha menunjukan kehebatannya dengan serius, penuh inovasi dan kreatifitas sehingga ia mampu membawa organisasi keluar dari mimpi buruk bahkan melebihi expectasi lingkungannya (Eacott, S., 2008)

Strategi ini ditunjukan oleh kepala sekolah taman kanak-kanak di Kota Cimahi yang terus berupaya melakukan peningkatan mutu sekolah pada masa Pandemi Covid 19. Dari hasil deskripsi penelitian ini, strategi yang diterapkan untuk meningkatkan mutu pendidikan taman kanak-kanak di masa Pandemi Covid 19 di Kota Cimahi sangat relevan untuk dilakukan, dengan demikian berdasarkan skor pengolahan data dan hasil analisis, bahwa strategi kepemimpinan kepala sekolah dalam meningkatkan mutu pendidikan adalah sebagai berikut (1) memperkuat manajemen sekolah melalui pendekatan proses (Process Approach); (2) melakukan analis potensi keunggulan sekolah yang bisa dikembangkan berdasarkan fakta (Factual approach) dalam meningkatkan mutu pendidikan; (3) melakukan kerjasama kolaborasi dengan semua pihak baik internal maupun eksternal dalam peningkatan mutu; (4) melibatkan pendidik dan tenaga kependidikan dalam peningkatan mutu serta memberikan kepercayaan penuh bagi tim dalam proses peningkatan mutu pendidikan taman kanak-kanak (Involvement of the people); (5) menciptakan perubahan, inovasi dan kreatifitas untuk mewujudkan mutu pendidikan taman kanak-kanak; (6) memperkuat fungsi leadership kepala sekolah baik sebagai manajer, administrator, educator, motivator, supervisor, innovator dan juga sebagai leader; (7) memperkuat pemahaman terhadap sistem pendidikan taman kanak-kanak, melalui pendekatan sistem (System Approach) baik visi, misi, tujuan dan sasaran, sistem pembelajaran dan selalu mempebaiki setiap hal yang dirasa perlu diperbaiki; (8) melakukan perbaikan dan pengembangan secara 
berkelanjutan (Continual improvement); (9) melakukan langkah-langkah yang sistematis dalam pembuatan keputusan untuk peningkatan mutu pendidikan tman kanak-kanak; (10)memberikan pelayanan prima terhadap pelanggan baik internal maupun eksternal; (11) fokus kepada pelanggan; (12) menerapkan prinsip keteladanan dalam setiap tindakan baik, menunjukan contoh yang mulia dalam kehidupan sehari-hari; (13) melakukan hubungan dengan pihak akademisi untuk proses peningkatan mutu pendidikan taman kanak-kanak; (14) bertanggung jawab dan menyelesaikan tanggung jawabnya sebagai kepala sekolah dengan baik.

Dengan demikian bahwa strategi kepemimpinan kepala sekolah dalam meningkatkan mutu pendidikan taman kanak-kanak pada masa pandemi Covid 19, merupakan upaya sistematis oleh kepala sekolah taman kanak-kanak dalam menjalankan kepemimpinannya di masa pandemi Covid 19. Hal ini dilakukan untuk menjaga kualitas yang telah dilcapai dan berupaya meningkatkan mutu taman kanak-kanak agar lebih baik di masa yang akan datang, strategi yang dilaksanakan di atas lebih difokuskan kepada bagaimana taman kanak-kanak sebagai satuan pendidikan mampu memposisikan peserta didik, orang tua dan masyarakat sebagai pelanggan. Taman kanak-kanak harus mengutamakan kepuasan pelanggan di atas dengan perilaku kepemimpinan kepala sekolah yang mampu diteladani, bertanggung jawab, memiliki prinsip melayani bukan ingin dilayani, mampu berkolaborasi dengan semua pihak, dan mampu menciptakan perubahan. Disamping itu kepala sekolah taman kanak-kanak adalah kepala sekolah yang melaksanakan program dengan pendekatan proses, sistem, mampu mengambil keputusan berdasarkan data dan fakta, mampu menjalin kerjasama dengan pihak luar dalam upaya peningkatan mutu serta senantiasa melakukan perbaikan perbaikan secara berkelanjutan. Dengan strategi itu semua maka peningkatan mutu taman kanak-kanak akan nampak di hari kemudian nanti.

\section{SIMPULAN}

Hasil penelitian dapat disimpulkan bahwa peranan kepala sekolah sangatlah penting dalam proses penyelenggaraan pendidikan. Taman Kanak-Kanak sebagai lembaga pendidikan formal pra sekolah, dengan segala keunikannya memerlukan pengelolaan professional, sebagai sarana tumbuh kembang anak secara sempurna baik secara kognitif, sikap maupun keterampilan. Di masa pandemi Covid 19 kepala sekolah TK harus memiliki langkah strategis agar sekolah mampu menciptakan rasa aman, kepuasan, dan tetap menjalankan program sekolah serta berusaha meningkatkan kualitas TK yang dipmpinnya. Hasil penelitian yang dilakukan pada kepala sekolah TK di Kota Cimahi menunjukan bahwa mereka telah melaksanakan peran kepemimpinannya dengan sangat baik dan berupaya optimal meningkatkan kualitas penyelenggaraan pendidikan.

\section{UCAPAN TERIMA KASIH}

Penulis menyampaikan ucapan terima kasih dan penghargaan yang setinggitingginya kepada Dewan Redaksi Jurnal Obsesi Pendidikan Anak Usia Dini, atas diterbitkannya artikel ini. Semoga Jurnal Obsesi Semakin sukses. Ucapan terima kasih juga saya sampaikan semua reviewer dan editor yang telah menelaah dan mereview artikel ini, untuk menjamin kualitas dan dampak substantif jurnal. Semoga Alloh SWT memberikan balasan yang berlipat ganda.

\section{DAFTAR PUSTAKA}

Adiwijaya (2020), Kesenjangan akses internet di Asia Tenggara jadi tantangan bagi pengajaran online akibat pandemi COVID-19, Artikel Detik. Net. Diakses 28 April 2020.

Agustin, Mubiar et.al (2020), Burnout Profile of Elementary School Teacher Education, Students (ESTES): "Factors and Implication of Guidance and Counseling Service". 
DOI: 10.31004/obsesi.v5i1.582

Journal of Elementary Education, Vol 4(1), 38-47. https://doi.org/10.22460/pej.v4i1.1640.

Agustin, Mubiar dan Puspita, R. (2020). Pengaruh Metode Karyawisata Terhadap Keterampilan Berbicara Pada Anak Sekolah Dasar, Jurnal Cakrawala Pendas, Vol 6 (1), 84-92.

Akdon (2011), Strategic Management For Education Management, Bandung: Alfabeta.

Arifin, Imron (2011), Strategi Kepala Sekolah dalam Mengimplementasikan PAUD Unggulan Nasional. Jurnal Pendidikan Dan Pembelajaran 18 (1), 36-46.

Anggraeni, G. N., \& Nurabadi, A. (2016). Implementasi Peran Kepala Taman Kanak-Kanak (TK) Dalam Meningkatkan Kinerja Guru. Jurnal Manajemen Pendidikan, Vol 25(1), 1017.

Banun, S., \& Usman, N. (2016). Strategi Kepemimpinan Kepala Sekolah Dalam Meningkatkan Mutu Pendidikan Pada SMPN Aceh Besar. Jurnal Administrasi Pendidikan Pascasarjana Universitas Syiah Kuala, Vol 4(1), 137- 147

Bell, L. (2010), School Leadership \& Management : Formerly School Organization, From Symphony To Jazz: The Concept Of Strategy In Education, Vol 18 (4) 37-41. Https:/ / Doi.Org/10.1080/13632439869420

Beritasatu (2020), Tingkat Kematian Covid 19 di Indonesia Tertinggi di Asia. Berita. www.beritasatu.com/kesehatan/625505. Diakses 26 April 2020.

Blomqvist, C., Agrell, C., \& Sandahl, C. (2016). Leadership Challenges Of Strategic Research Centres In Relation To Degree Of Institutionalisation, Journal of Higher Education $\begin{array}{llll}\text { Policy and Management, } & \text { 1-16. }\end{array}$ Https://Doi.Org/10.1080/1360080x.2016.1211969

Botha, R. J. N., \& Triegaardt, P. K. P. (2017). Distributive Leadership As Management Strategy For School Effectiveness : The Place And Role Of The Oscar Coaching Model In South, African Schools, Journal of Social Sciences, Vol 40 (2): 251-260, Https:/ / Doi.Org/10.1080/09718923.2014.11893322

Bush, Tony \& Coleman, M. (2012). Manajemen Mutu Kepemimpinan Pendidikan. Diterjemahkan Fahrurrozi. Jogjakarta: IRCiSoD

Cheng, Y. C. (2003), Quality Assurance In Education: Internal, Interface, And Future, Quality Assurance in Education Journal, Vol 11(4), 202-213. https://doi.org/10.1108/09684880310501386.

Creswell, J. W. (2012). Research design: pendekatan kualitatif, kuantitatif, dan mixed. Yogjakarta: PT Pustaka Pelajar

Darling, J. R. (1992). Total Quality Management: The Key Role of Leadership Strategies. Leadership \& Organization Development Jounal, Vol 13(4), 2-7. https://doi.org/10.1108/01437739210013388.

Depdiknas (2003). Undang-undang RI No.20 tahun 2003. Tentang Undang - undang Sistem Pendidikan Nasional.

Eacott, S. (2008). Theory And Practice An Analysis Of Contemporary Literature On Strategy In Education, International Journal Of Leadership In Education, Vol 11 (3), 37-41. Https://Doi.Org/10.1080/13603120701462111

Erlandson, D. A. (2014). Performance Standards For The Principalship: Emergence Of Available Model, School Leadership and Management. Vol 10(1), 11-25. Https:/ / Doi.Org/10.1080/0260136900100102

Fadhli, M. (2017). Manajemen Peningkatan Mutu Pendidikan, Jurnal Studi Manajemen Pendidikan, Vol 1(02), 216-240. https:/ / doi.org/10.29240/jsmp.v1i2.295.

Hoy, Wayne K., Miskel, Cecil G.2005. Educational Administration Theory, Research, and Practice. Seventh Edition. New York: Mc Graw Hill.

Hoyle, D. 2007. Quality Management Essentials. Oxford: Elsevier Limited. https://doi.org/10.4324/9780080471396.

Jones, C., \& Pound, L. (2008). Leadership and Management in the Early Years from principles to 
practice. London: Open University Press.

Juliantoro, O. M. (2017). Peran Kepala Sekolah dalam Meningkatkan Mutu Pendidikan. Junal Al-Hikmah, 5 no.(2).

Kolesar, Peter J. (1994), What Deming Told the Japanese in 1950 : Critical Evaluations in Bussines and Management, Quality Management Journal, Vol 2(1), 9-24. https:// doi.org/10.1080/10686967.1994.11918672.

Kompasiana (2020), Dampak Virus Corona Berimbas Bagi Pendidikan Saat Ini di Indonesia, Berita Edukasi. www.kompasiana.com/rezzawidiautami3362/5e7ded93097f36393028cec2 Diakses 05 Maret 2020.

Kompasiana (2020), Tingkat Kematian Covid 19 dunia 57 Juta Orang Terinfeksi dan 350 Ribu Orang Meninggal Dunia. Berita Edukasi. www.kompas.com/tren/read/2020/05/28/091305865. Diakses 28 Mei 2020.

Mahbub, M., Purnamawati, D., Maslamah, Sopakua, S., \& Fauziddin, M. (2020). Educational data mining with clustering technique on the distribution of civil servant teachers in Indonesia. Journal of Advanced Research in Dynamical and Control Systems, 12(6), 2097-2103. https:// doi.org/10.5373/JARDCS/V12I6/S20201171

Markides, C. (2004). What Is Strategy And How Do You Know If You Have One ?, Business Strategy Review Summer, vol 15 (2), 5-12. https://doi.org/10.1111/j.09556419.2004.00306.x.

Mulyasa (2012). Manajemen dan Kepemimpinana Kepala Sekolah, Jakarta: Bumi Aksara.

Northouse, G. Peter. (2013). Kepemimpinan: Teori dan Praktek. Cet. VI; Jakarta: Penerbit Indeks.

Nanda, Vivek. (2005) Quality Management System Handbook For Product Development Companies. Florida : Crc Press. https:// doi.org/10.1201/9781420025309.

Patterson, W. G. (2016). How To Obtain A Principalship, A Journal of Educational Strategies, Issues and Ideas, Vol 44 (5), 310-314. https:/ / Doi.Org/10.1080/00098655.1970.11478391

Peraturan Pemerintah Nomor 19 Tahun 2005 tentang Standar Nasional

Rivai, Veithzal. (2004). Kepemimpinan dan Perilaku Organisasi. Jakarta: Raja Grafindo Persada.

Rodd, J. (2006). Leadership In Early Childhood. Australia: National Library of Australia.

Saifulloh, M., \& Zainul Muhibbin, H. (2012). Strategi peningkatan mutu pendidikan di sekolah. Jurnal Sosial Humaniora, Vol 5(2), 206-218. https:// doi.org/10.12962/j24433527.v5i2.619.

Sallis, E, (2012), Total Quality Management in Education, Alih Bahasa, Ahmad Ali Riyadi dan Fahrurrozi, IRCiSoD, Yogyakarta.

Sari, H. (2016). Kepemimpinan yang Melayani di Sekolah Menengah Tingkat Atas Swasta Kota Salatiga. Jurnal Manajemen Pendidikan, Vol 3(2), 265-276. https:// doi.org/10.24246/j.jk.2016.v3.i2.p265-276.

Sa'ud, Udin S. (2004). Manajemen Mutu Terpadu. Alfabeta : Bandung

Suarga. (2017). Efektivitas penerapan prinsip-prinsip kepemimpinan kepala sekolah terhadap peningkatan mutu layanan administrasi pendidikan. Jurnal Idaarah, Vol 1(20), 23-33. https://doi.org/10.24252/idaarah.v1i1.4081.

Stephen J. Bagnato. (2007). Intervention, Authentic Assesment For Early Childhood. New York: The Guilford Press.

Sturm, R. E., Vera, D., \& Crossan, M. (2016). The Entanglement Of Leader Character And Leader Competence And Its Impact On Performance. The Leadership Quarterly. Vol xxx (2016), 1-17. https://Doi.Org/10.1016/J.Leaqua.2016.11.007

Tambunan Sony (2015). Pemimpin dan Kepemimpinan. Cet I; Yogyakarta: Graha Ilmu.

Wahjosumidjo. 2007. Kepemimpinan Kepala Sekolah, Tinjauan Teoritik dan Permsasalahannya, Jakarta: PT. Raja Grafindo Persada. 